\title{
YouTube for Rapid Sequence Intubation Learning, Is It Reliable?
}

\section{Hızlı Seri Entübasyon Öğrenimi için YouTube Güvenilir Bir Kaynak Mı?}

\author{
Ali Haydar Akça , Muhammed İkbal Şaşmaz \\ Van Yüzüncü Yal Üniversitesi Tip Fakültesi, Acil Tep Ana Bilim Dalı, Van
}

\begin{abstract}
Objective: We aimed to evaluate the educational videos about rapid sequence intubation (RSI) and their compliance with ACLS-RSI guideline on the worlds biggest video-sharing site, YouTube.

Methods and Methods: The search was conducted on February 1, 2017 by using the terms "rapid sequence intubation" and "rapid sequence induction and intubation" and evaluated 200 videos according to this results. All the videos were viewed by two emergency physicians who were blinded to each other and were scored between 0 and 7 points.

Results: 147 videos excluded and study group was composed of 53 videos. As total score; $17(32.1 \%)$ videos received less than 3 points, $19(35,8)$ videos received between 3 and 5 , and $17(32.1 \%)$ of them received more than 5 . The videos uploaded by an institution had higher points however it was not statistically significant $(\mathrm{p}=0.566)$.

Conclusion: As a result, our study revealed that majority of the videos about rapid sequence intubation on YouTube are not compliant with ACLS-RSI guideline. Most of the uploaders did not elaborate recommendations of the guideline.
\end{abstract}

Key Words: Rapid sequence intubation, YouTube, medical education

\section{Introduction}

Intubation is a crucial procedure performed by emergency physicians in emergency departments (ED) (1). Rapid sequence intubation (RSI) is an airway management technique that produces inducing immediate unresponsiveness (induction agent) and muscular relaxation (neuromuscular blocking agent) and is the fastest and most effective means of controlling the emergency airway. RSI is particularly useful in emergency departments because of its protective features with a patient with a full stomach and intact gag reflex, who has a life threatening injury and require immediate airway control (2). RSI is the recommended method for emergency airway management (3).

\section{ÖZET}

Amaç: Bu çalışmada, dünyanın en büyük video paylaşım sitesi olan YouTube'daki hizlı seri entübasyon videolarını değerlendirmeyi ve onların ACLS-RSI (Advanced Cardiac Life Support- Rapid Sequence Intubation) k1lavuzlar1 ile uygunluğunu değerlendirmeyi amaçladık.

Gereç ve Yöntem: 1 Şubat 2017 tarihinde YouTube kaynağında "rapid sequence intubation" ve "rapid sequence induction and intubation" anahtar kelimeleri kullanılarak yapılan arama sonucu bulunan 200 video çalş̧maya dahil edildi. $\mathrm{Bu}$ videolar birbirlerinden bağımsız iki ayrı acil tıp uzmanı tarafindan 0 ve 7 puan aralığında değerlendirildi.

Bulgular: 147 video dişlanarak 53 video çalışma grubunu oluşturdu. Bu videolardan 17'si (\%32.1) toplamda 3 ya da daha düşük puan alırken, 19'u (\%35.8) 3 ve 5 arasında, 17'si (\%32.1) 5 puanın üzerinde değerlendirildi. Bir kurum tarafından yüklenen videoların puanları daha yüksekti ancak bu yükseklik istatistik olarak anlamlı değildi ( $\mathrm{p}=0.566)$.

Sonuç: Sonuç olarak, YouTube kaynağındaki hızlı seri entübasyon videolarının çoğunluğu ACLS-RSI kılavuzlarına uygun değildi. Yükleyicilerin çoğu kılavuz önerilerini dikkate almamıștı.

Anahtar Kelimeler: Hızlı seri entübasyon, YouTube, tıp eğitimi

In emergency setting, definitive airway must be delivered to cardiopulmonary arrest patients in no time with crash intubation. However for other patients who requires ventilation support should undergo RSI process (4).

Advanced Cardiac Life Support (ACLS) guideline also recommends RSI technique (5).

RSI consists of 7 steps which is known 7Ps;
1. Preparation
2. Preoxygenation
3. Pretreatment
4. Paralysis with induction
5. Protection and positioning
6. Placement with proof
7. Post-intubation management 
Airway management is one of the crucial specialty of both emergency physicians and anesthesiologists. Therefore, they should be well-trained about this process. Traditional training in airway management relies on use of airway mannequins and intubations in the controlled setting of the operating room in fasting, preoxygenated patients (6).

On the other hand, videotape educational review has an important role in training individuals. Health professionals also use internet and video-sharing sites for educational purposes with increasing rates over years. (7).

In this study, we aimed to evaluate the educational videos about rapid sequence intubation (RSI) on the worlds biggest video-sharing site, YouTube. And also we focused on collecting preliminary information both for medical staff using YouTube for education and the ones producing content for that staff.

\section{Material and Method}

We conducted a search on YouTube on February 1, 2017 by using the terms "rapid sequence intubation" and "rapid sequence induction and intubation" and evaluated 200 videos according to these results. Our exclusion criterias were as follows:

* Videos that were uploaded before 2010

* Videos on any other subjects other than RSI

* Video language other than English

* Recurrent videos

* Videos with ads

* Videos not for educational purposes

The videos in the study group were evaluated in terms of the uploader, length of video, view count and use of models or human subjects for practice. All the videos were scored between 0 and 7 points by two emergency physicians and they were blinded to each other. The scoring criteria were based on ACLS - RSI guideline (updated 2014) (Table 1). When two viewer scored different values for the same video, the average of two scores was accepted as final score. We assumed videos receiving scores higher than 5 as sufficient.

Statistical Analysis: The data was analysed by SPSS 18.0 software. Numeric variable was presented as median (IQR: interquartile ratio) and frequent variables as rates. Two group comparisons for numeric variables were performed by Mann Whitney $\mathrm{U}$ test and Kruskal Wallis test was performed for three or more group comparisons. Normality analysis was performed by Shapiro Wilks test. All the hypothesis was constructed as two tailed and alpha critical value of 0.05 was accepted as significant.

Table 1. The scoring criteria *

\begin{tabular}{lc}
\hline Intervention $(7 \mathrm{p})$ & Score \\
\hline Preparation & 1 \\
Preoxygenation & 1 \\
Pretreatment & 1 \\
Paralysis with induction & 1 \\
Protection and positioning & 1 \\
Placement with proof & 1 \\
Post intubation management & 1 \\
\hline
\end{tabular}

*Based on Advanced Cardiac Life Support (ACLS): Rapid Sequence Induction and Intubation

\section{Results}

We found 200 videos with given search terms and 147 of them were excluded in accordance with exclusion criteria. Remaining 53 videos constituted the study group (Figure 1). Two independent emergency physician viewed and scored the study group.

In study group, the most viewed video had 568854 view count and least viewed had 17 and mean view count of study group was 53218 (mean:53218, std dev. 1,143). $23(43,4 \%)$ videos had more than 10.000 views.

In our study group, the shortest video was 55 seconds and the longest was 1 hour 9 minutes 29 seconds. Mean length was 10 minutes 36 seconds.

Capnography for verification of tube placement, as suggested in AHA-ERC guidelines, was mentioned in $25(47.2 \%)$ of 53 videos.

$22(41,5 \%)$ videos showed RSI practice on human, 17 $(32,1 \%)$ showed on mannequins, $13(24,5 \%)$ on both and $1(1,9 \%)$ used none.

As total score; $17(32,1 \%)$ videos received less than 3 points, $19(35,8)$ videos received between 3 and 5, 17 $(32,1 \%)$ of them received more than 5 points.

The characteristics of the videos in the study are shown in table 2 .

Median score of the videos was 4 (IQR:3-5). According to upload year; despite median score of videos in 2015-2016 was higher than that of 20102012 and 2013-2014 years, that was not statistically significant. 
Table 2. Characteristics of the videos

Upload date (year)

2010

2011

2012

2013

2014

2015

Uploader type

Institutional (University, Society...)

Individual

Unknown

View count

$<10000$

$\geq 10000$

Mentioned capnography for verification?

Yes

No

RSI application on

Human

Mannequin

None

$13 \quad 24,5$

Both

Total scores received

$\leq 3$ points $(1-2-3)$

$3<x \leq 5$ points $(3,5-4-4,5-5)$

$>5$ points $(5,5-6-6,5-7)$

17

Total 
Table 3. Video scores in terms of variables

\begin{tabular}{lll}
\hline Variables & $\begin{array}{l}\text { Score } \\
\text { Median } \\
\text { (IQR) }\end{array}$ & $\begin{array}{l}\mathrm{p} \\
\text { value }\end{array}$ \\
\hline Upload date (year) & & \\
$2010-2012$ & $4(2,50)$ & 0,565 \\
$2013-2014$ & $4(2,50)$ & \\
$2015-2016$ & $5(3,00)$ & \\
Uploader type & & \\
Institutional (University, & $5(2,00)$ & 0,566 \\
Society...) & $4(2,00)$ & \\
Individual & $4(3,00)$ & \\
Unknown & \\
View count & $4,5(3,00)$ & 0,622 \\
$<10000$ & $4 \quad(2,00)$ & \\
$\geq 10000$ &
\end{tabular}

t[5 (IQR: 3) vs 4 (IQR: 2,5), 4(IQR:2,5), $\mathrm{p}=0.565)]$. When we evaluate the uploader type; median score of the institution group was higher than other groups however that was not statistically significant [5 (IQR: 2) vs 4 (IQR: 2), 4(IQR:3), $\mathrm{p}=0.566)]$. The comparison of video scores in terms of variables is presented in Table 3.

\section{Discussion}

YouTube is one of the biggest video-sharing site of the world. Due to its accessibility, it allows uploader to communicate and share information with people around the world. Healthcare personnel and medical students use internet and video-sharing sites for educational purposes especially for interventional procedures (7).

Airway management is one of the most important skills for an emergency physician to master because failure to secure an adequate airway can quickly lead to death or disability (8).

Endotracheal intubation with rapid sequence intubation (RSI) technique is the cornerstone of emergency airway management $(9,10)$. Several studies show that RSI is a safe and effective way of airway management $(11,12)$

\section{Videos according to search terms on \\ YouTube}

200 videos

\section{7 videos excluded}

- Off-topic ( $\mathrm{n}=47$ )

- Language other than English ( $\mathrm{n}=8)$

- Advertisement videos ( $\mathrm{n}=3$ )

- Recurrent videos ( $\mathrm{n}=86$ )

- Live action video not for educational purposes $(\mathrm{n}=1)$

- Uploaded before $2010(\mathrm{n}=2)$
Study group: 53 videos

Fig. 1. Video flow chart 
That's why all emergency physicians supposed to be well-trained about rapid sequence intubation and must master all steps of the procedure.

In this study, we analyzed the videos due to our search on YouTube with terms "rapid sequence intubation" and "rapid sequence induction and intubation" according to ACLS-RSI guideline. Despite there are some analyses of video-sharing sites on various topics like trauma management and cardiopulmonary resuscitation in scientific databases, there are no studies about endotracheal intubation (13). In that point, our study is the pioneer.

Median score of total study group was 4 on total score of 7 (IQR:3-5) and it is not satisfactory as medical teaching video. Although videos uploaded by institutions had higher median score than other groups, that was not statistically significant. On the other hand, this might be a limitation of low number of videos in study group (n:53).

At the same time, whilst capnograhy is highly recommended for verification of tube position, 52,8\% of the videos did not mention capnography (5).

In our opinion, there are several aspects that might be harmful by spreading inappropriate information. First of all, score of videos did not have any correlation with view counts and rankings in YouTube search. Similar studies showed the same result in different topics (14). Secondly, YouTube users can upload videos regardless of their knowledge of health, professionalism and medical qualities. View counts indicate that the audience take no account of the quality of uploader (13). Lastly, even institutions can upload insufficient videos, there is no mechanism to check the sufficiency and quality of videos. When we conceive that healthcare providers increasingly use internet sources for educational purposes, these data has to be uploaded with supervision.

As a conclusion of this study, in order to maintain video reliability and quality, video sharing sites should seperate these videos into another tab like academic or educational and supply some supervision to this type of videos.

Limitations : YouTube is a dynamic platform so it's content is varying day by day. We performed this study in a specific timeline and it is possible that more videos has been added about this topic. Additionally, we are not sure if we could achieve all videos about RSI with these search terms.

\section{Conclusion}

As a result, our study revealed that majority of the videos about rapid sequence intubation on YouTube are not compliant with ACLS-RSI guideline. Most of the uploaders did not elaborate recommendations of the guideline. As much as healthcare providers and medical students use internet sources for educational purposes, supervision will become a requirement for academic internet use. We aimed to flash on and give preliminary information to content makers for medical education.

Conflict of Interest: All authors declare that they have no conflict of interest.

\section{References}

1. Brown CA 3rd, Bair AE, Pallin DJ, Walls RM. Techniques, success, and adverse events of emergency department adult intubations. Ann Emerg Med 2014; 65(4): 363-370.

2. Bernhard M et al. The First Shot Is Often the Best Shot: First-Pass Intubation Success in Emergency Airway Management. Anesth Analg 2015; 121(5): 1389-93.

3. Walls RM, Brown CA, 3rd, Bair AE, Pallin DJ, Investigators NI. Emergency airway management: a multi-center report of 8937 emergency department intubations. J Emerg Med. 2011;41(4):347-354.

4. http://emedicine.medscape.com/article/80222overview

5. ACLS - Rapid Sequence Induction Updated: Mar 21, 2014. Author: James J Lamberg, DO; Chief Editor: Meda Raghavendra (Raghu), MD.

6. Gott L, Randel G, Straker T, et al. A survey of airway training among US and Canadian anesthesiology residency programs. J Clin Anesth. 2001;23(1):15-26.

7. Nason GJ, Kelly P, Kelly ME, Burke MJ, Aslam A, Giri SK, et al. YouTube as an educational tool regarding male urethral catheterization. Scand J Urol 2015; 49(2): 189-192.

8. Reynolds SF, Heffner J. Airway management of the critically ill patient: rapid-sequence intubation. Chest. 2005; 127(4): 1397-412.

9. Bair AE, Filbin MR, Kulkarni RG, Walls RM. The failed intubation attempt in the emergency department: analysis of prevalence, rescue techniques, and personnel. J Emerg Med 2002; 23(2): 131-140.

10. Sagarin MJ, Barton ED, Chng YM, Walls RM; National Emergency Airway Registry Investigators. Airway management by US and Canadian emergency medicine residents: a multicenter analysis of more than 6,000 endotracheal intubation attempts. Ann Emerg Med 2005; 46(4): 328-336.

11. Sakles JC. Improving the Safety of Rapid Sequence Intubation in the Emergency Department. Ann Emerg Med 2017; 69(1): 7-9.

12. Okubo M, Gibo K, Hagiwara Y, Nakayama Y, Hasegawa K; Japanese Emergency Medicine Network Investigators. The effectiveness of rapid sequence intubation (RSI) versus non-RSI in emergency 
Akça ve ark. / Rapid sequence intubation on Youtube

department: an analysis of multicenter prospective observational study. Int J Emerg Med 2017; 10(1): 1.

13. Şaşmaz MI, Akça AH. Reliability of trauma management videos on YouTube and their compliance with ATLS ${ }^{\circledR}$ (9th edition) guideline. Eur J Trauma Emerg Surg 2017 Jun 1.
14. Ho M, Stothers L, Lazare D, Tsang B, Macnab A. Evaluation of educational content of YouTube videos relating to neuro- genic bladder and intermittent catheterization. Can Urol Assoc J 2015; 9(9-10): 320324. 